\title{
Anti-teratogenic potential and curtailing toxicity of valproic acid
}

\begin{abstract}
Valproic acid (VPA) is widely used as an anticonvulsant and mood-stabilizing drug. It is highly prescribed drug, particularly for epilepsy. However, besides beneficial VPA have a number of side effects due to affecting several signaling pathways through different mechanisms. VPA act as a potent teraogen causing birth defects via interfering with folate metabolism or oxidative stress generation, and histone deacetylase inhibition. However, this article aims to give an overview of the these adverse consequences of VPA are significantly curtailed by the various substances like Vitamin E, Ascorbic Acid, Folic acid, Pantothenic acid, S-adenosyl methionine (SAM) and Curcumin etc which can be focus on its therapeutic use in future against it because of no such other alternative.
\end{abstract}

Volume 4 Issue 4 - 2018

\author{
Akhilesh Kumar, 'Vimala Bind² \\ 'Toxicology Division, India \\ ${ }^{2}$ Dept of Zoology, KN Govt PG College Gyanpur, India
}

Correspondence: Akhilesh Kumar, Consultant (Toxicology), Toxicology Division, CIB \& RC, Faridabad, Haryana, India, Tel +91-9565490 599, Email akhilcibrc@gmail.com

Received: July 10, 2018 | Published: August 08, 2018

Keywords: VPA, vitamin, epilepsy, birth defects, anticonvulsant

\section{Introduction}

VPA has become one of the most widely prescribed antiepileptic drugs worldwide in the management of long-term epilepsy, as well as controlling several neurological disorders including tonic-clonic seizures, idiopathic generalized seizures, juvenile myoclonic epilepsy, and childhood absence seizures and migraines. ${ }^{1,2}$ Valproic acid, VPA (2-n-propylpentanoic acid, $\left.\mathrm{C}_{8} \mathrm{H}_{15} \mathrm{NaO}_{2}, \mathrm{MW}-166.19\right)$ a branched short-chain fatty acid derived from naturally occurring valeric acid was first synthesized in $1882 .{ }^{3}$ It is known teratogenic agent for women of childbearing age and classified as a Type Dcategory indicating that human fetal risk has been documented but the use of the drug may still be warranted. ${ }^{4}$

\section{Teratogenic profile and potential mechanisms}

The teratogenic potential of VPA has been highlighted by numerous case reports ${ }^{5}$ and in epidemiological studies. ${ }^{6,7}$ These clinical findings suggest that VPA therapy during pregnancy may produce neural tube defects, most notably spina bifida (in human), as well as cardiovascular, urogenital, craniofacial, and digital abnormalities. An assortment of malformations related to prenatal VPA exposure have also been reported in laboratory species, including mice, ${ }^{8,9}$ rats, ${ }^{10}$ rabbits, ${ }^{11}$ and rhesus monkeys. ${ }^{12}$ The incidence associated with NTDs in exposed infants use VPA treatments, which is 10-20 times higher the rate of occurrences in general population. ${ }^{13}$ In addition with congenital malformations, ${ }^{14}$ a characteristic facial phenotype in VPAexposed infants which have facial appearance like a broad nasal root, long and thin upper lip, epicanthic folds, small upturned nose, minor abnormalities of the ears and downturned angles of the mouth.

VPA-induced teratogenicity is too much complicated beside this the studies have been demonstrate that the VPA affect several signaling pathways through different mechanisms. Generally, birth defects due to VPA exposure reported three major hypotheses are i.e. Folate deficiency, oxidative stress, and histone deacetylase inhibition. VPA interfering with folate metabolism reported earlier thereby inhibiting the production of one-carbon units for DNA synthesis and methylation. ${ }^{15}$ If used daily about $4-5 \mathrm{mg}$ folic acid during pregnancy decreased the incident of spontaneous abortion in women, although the rate of congenital malformations was not affected. ${ }^{15,16}$ Modification of histone post-translationally by acetylation, methylation along with other process such as, phosphorylation, and ubiquitination can modify the chromatin conformation, consequential in changes in gene activity. The nucleosome (functional unit of chromatin) is consists of about 146 base pairs of DNA wrapped around the octamer of histone consisted H2A, H2B, H3, and H4 in dual. ${ }^{17}$ These modifications lead to altered DNA and histone proteins interactions, or trigger recruitment of chromatin remodeling complexes to further regulate gene activity. During acetylation masks the positive charge on lysine residues on histone tails resulting in a weakened DNA/histone interaction, thereby inducing a relaxed chromatin structure that allows DNA access to transcription factors. ${ }^{18}$ Furthermore, acetylation can serve as a marker for other proteins that can then recruit chromatin remodeling and other functional complexes to modulate gene expression. ${ }^{19}$ Histone acetylation is dictated by the balance of histone deacetylases (HDACs) and histone acetylases (HATs). HDACs are responsible for the removal of acetyl groups on histones as well as other proteins. Histone acetylation is carried out by HATs by transferring an acetyl group from acetyl coenzyme A (acetyl CoA) onto lysine residues on histone tails. Treatment with HDAC inhibitors could be de-repressing transcription about $2 \%$ of genes, out of which many regulate cell cycle and cellular differentiation. ${ }^{20}$ Its inhibition is to be expected explanation for their effects on proliferation and differentiation in transformed cells. ${ }^{21}$ Many example of HDAC inhibitors block proliferation and induce differentiation in cancers models such as leukemia and colon, lung, and prostate carcinoma. ${ }^{22} \mathrm{HDAC}$ inhibition as factors for teratogenicity first time reported by Phiel et al. ${ }^{23}$ Similar result reported by Gurvich and colleagues in Xenopus and zebrafish embryos. He explained VPA induced teratogenicity via changing gene expression; using microarray for genes targeted which is also targeted by TSA inducing teratogenesis, and finally suggested that gene expression changes were being induced by structurally unrelated two drugs via a similar mechanism. ${ }^{24}$

\section{Valproic acid-induced teratogenesis via oxidative stress}

Oxidative stress responsible for causing damage in the building material of cellular macromolecules such as DNA, lipids, and proteins, along with changing redox-sensitive signaling pathways 
leading malformation during development. ${ }^{25}$ Hydroxyl ion (OH-) is react with nitrogenous bases and it one of the facts of oxidative DNA damage. Generated free radicals can also react with polyunsaturated fatty acids to form electrophilic aldehydes such as malondialdehyde (MDA) and 4-hydroxy-2-nonenal (HNE) that adducts bind with the amino acids like cysteine, lysine, or histidine residues and thus interfere with protein function. Beside this, the gene expression is precisely regulated during development; ROS can change the pathway of transcription factors by disturbing cell signaling, therefore disrupt normal embryonic development and result in a teratogenic effect. ${ }^{26}$ Oxidative stress is one of the significant mechanisms that involves in embryonic metabolism or bioactivation of an exogenous agent such as drugs or chemicals, which produced ROS, inducing cellular damage or altered signaling and finally teratogenesis. ${ }^{25,27}$ Many works have reported that the levels of catalase, superoxide dismutase (SOD), and glutathione peroxidase (GSH-Px) are low during organogenesis period embryos as compared to adult. ${ }^{28}$ During early embryonic development Cytochrome P450s (CYPs) are the most important enzymes implicated in the metabolism of drugs and some of the forming metabolite involve in generating ROS. Hence applying antioxidative compounds and enzymes would protect harmful effects against ROS and this has also been supported by reports of various workers. ${ }^{29}$

During embryonic period, occurred anaerobic metabolism in embryo so, the risk of oxidative tone is toxic for them. Supply of oxygen required for the rapid growth and weight gain which come from utero-placental circulation. If any fluctuations in the development period due to oxidation are referred to as redox switching, because oxygen levels are maintained to sustain the cellular actions during critical periods of organogenesis. For the rapid proliferation of cells low oxygen levels are required and generated mild oxidative tone leads to cellular differentiation whereas at high oxidative environment results in apoptosis or necrosis of the developing cells. ${ }^{30}$ If in this time (organogenesis period) any xenobiotics or drugs which enhance oxidative stress which very sensitive to oxidative tone, causing necrosis or apoptosis or uncontrolled differentiation ultimately resulting very harmful effects in the form of teratogenic effect or birth defects. Previous studies have reported VPA can induce oxidative stress and this is one of the reasons for occurring teratogenicity. ${ }^{31}$ The VPA metabolites such as 4-ene VPA, 2-ene VPA and 2, 4-diene VPA, form by CYP metabolism in liver. This metabolite interact with GSH depleted their levels, so the balance of cellular system in antioxidant decrease and condition become very sensitive but by supplementation with any natural or synthetic antioxidants such as catalase, vitamin $\mathrm{C}$, and vitamin $\mathrm{E}$ protected against damage induced by 4-ene VPA was reported in various study. ${ }^{32}$ VPA induced ROS formation has been determined by measurement of the conversion of the non-fluorescent ROS-sensitive dye 5-(and-6)-chloromehtyl$2^{\text {ee }} 7^{\text {ee }}$-dichlorodihydrofluorescein diacetate (CM-H2DCFDA) to the fluorescent dichlorodihydrofluorescein (DCF) in various cell line and it attenuated by antioxidant such as PEG-catalase ${ }^{33}$ or with vitamin $\mathrm{E}^{34}$ or vitamin $\mathrm{C}^{35}$ was reported, which clarify the role of protective effects (Table 1).

\section{Anti-teratogenic agents against VPA induced teratogenesis}

Women taking anticonvulsant medications during gestation of the first trimester ${ }^{36}$ have a 3-5\% greater risk of birth defect in an infant than whom not taking ${ }^{37}$ VPA during pregnancy. The risk of spina bifida occurring is more than or 20 times greater risk than in the general population and about 10 times more observed in other antiepileptic drugs. ${ }^{38}$ Various compounds have been used against VPA to reduce or compensate its toxic/teratogenic effects in various animal models. In NMRI mice combination of the three vitamins (Folinic acid, vitamin B6, and vitamin B12) was found effective in reducing VPA $(500 \mathrm{mg} /$ $\mathrm{kg}$, subcutaneous) induced exencephaly, spina bifida occulta, palate and rib malformations. ${ }^{39}$ In1996, Methionine $(70 \mathrm{mg} / \mathrm{kg}$ ) reduces VPA-induced spina bifida in mice without altering VPA kinetics. ${ }^{40}$ Methionine, an essential amino acid is required for normal growth and development in mammals. ${ }^{41}$ Coelho and co-workers (1989) found it also important for neural tube development, in cultured rat embryos. Further studies revealed that in the absence of methionine the neural tube failed to close in cultured rat embryos ${ }^{42}$ because methionine may be required for the methylation of microfilament proteins involved in neural fold apposition. In humans, methionine metabolism or derangement of homocysteine metabolism has been reported as a possible risk factor in neural tube defects.

In 2000, Al Deeb and its co-worker studied with vitamin E and reported concomitant administration of vitamin E $(250 \mathrm{mg} / \mathrm{kg})$ significantly attenuated VPA $(700 \mathrm{mg} / \mathrm{kg}$, subcutaneous) induced decrease in the fetal weight, crown rump length and malformations (exencephaly, open eyelid, and micrognathae) in Balb mice (Table 1) and another study also reported that its alteration on glutathione homeostasis (GSSG/ GSH ratio) along with inhibiting Hoxa2 expression induced teratogenesis prevented after Pretreatment with ascorbic acid. ${ }^{34}$ In 2003, three doses of $4 \mathrm{mg} / \mathrm{kg}$ folic acid (FA) (total $12 \mathrm{mg} / \mathrm{kg}$ ) supplementation during gestation (GD 7) or FA (4 mg/kg) was administered thrice daily starting on GD 5 and continued through GD 10 substantially reduced exencephaly in mouse fetuses ${ }^{43}$ (Table 1). Later protective effects of folic acid and pantothenic acid against valproic acid-induced neural tube defects in CD-1 mice has been also reported. ${ }^{16}$ In 2001, Fenech reported low levels of folic acid causes breaks of chromosome, hypomethylation of DNA and micronucleus formation. Low levels of methionine increase the level of homocysteine that have been implicated in NTD. ${ }^{44}$ Homocysteine was a biomarker of folate status. ${ }^{45}$ It has been observed elevated moderately levels of homocysteine in maternal blood and amniotic fluid of pregnancies causing neural tube defects, NTD. ${ }^{46}$ Homocysteine has been shown to induce malformations in chick and rat embryos, ${ }^{47,48}$ observed that folic acid and vitamin B 12 are independent risk factors for NTD.

Another mechanism exhibited with one of the key enzyme Methylenetetrahydrofolate reductases (MTHFR) involve in folate interconversion and homocysteine metabolism. VPA might interfere with folate metabolism through MTHFR modulation that increase teratogenicity rate. ${ }^{49}$ The enzyme methylenetetrahydrofolate reductase (MTHFR) catalyses the production of 5- methytetrahydrofolate, a substrate for methionine synthase in folic acid cycle. Reduced activity of MTHFR results in elevated levels of homocysteine and thus diminishes the supply of methyl groups to macromolecules via folatehomocysteine cycle. A thermolabile variant of MTHFR is reported to occur frequently among NTD cases and their families than among controls. ${ }^{50,51}$ So, NTD in fact after administration of folic acid cannot prevent because of many reason for its happening. Further studies are required to clarify certain basic issues in the nutritional requirements of embryos during normal and abnormal morphogenesis of the neural tube defects and other various congenital malformations.

Another in invivo study done in rats further supported it by attenuating VPA-induced skeletal malformations by pretreatment of 
vitamin E. ${ }^{52}$ In human patients VPA therapy increased the oxidative stress by lower antioxidant activities, ${ }^{53,54}$ in various cell line. ${ }^{33}$ Recently published study on administration Valproic acid (VPA) at a dose of $300 \mathrm{mg}$ per kg body wt significantly decreased the levels of GSH, SOD and catalase and increased the levels of ROS, TBARS, mRNA expression and the levels of the CYP2C9 enzyme which is involved in the formation of the toxic metabolite $(E)$-2,4-diene-VPA. However, upon the co-administration of curcumin at the dose of 100 , 150 and $200 \mathrm{mg}$ per kg body wt. along with $300 \mathrm{mg}$ per $\mathrm{kg}$ body wt of VPA, confirmed the significant increase levels of GSH, SOD and catalase and reduced the ROS, TBARS, mRNA expression and the level of CYP2C9 enzyme with respect to VPA (Table 1). This study also conclude the formation of toxic metabolite $(E)$-2,4-diene-VPA is involved in the generation of oxidative stress subsequently contributing in the induction of malformations and anomalies. However, curcumin affords dose dependent amelioration of the anomalies in fetus exerted by VPA. ${ }^{56} \mathrm{~A}$ number of plant products have been reported to have excellent source of antioxidant with no side effects, in most of the published articles. Folic acid, vitamins and various plant products in various form now used as protective, prophylactic or ameliorative form..$^{57-59}$

Table I List of herbal products acting antiteratogen activity

\begin{tabular}{|c|c|c|c|c|c|c|}
\hline Antiteratogen & $\begin{array}{l}\text { Dose of } \\
\text { antiteratogen }\end{array}$ & Teratogen & $\begin{array}{l}\text { Dose of } \\
\text { teratogen }\end{array}$ & $\begin{array}{l}\text { Species/ } \\
\text { System }\end{array}$ & Reported effects & Source \\
\hline Folinic acid (FA) & $\begin{array}{l}4 \mathrm{mg} / \mathrm{kg} / \mathrm{d} \text { on } \\
\text { days } 8,9, \text { and } 10\end{array}$ & Valproate (VPA) & $\begin{array}{l}300 \mathrm{mg} / \mathrm{kg} / \mathrm{d} \\
\text { on days } 8,9 \\
10 \text { of } \mathrm{GD}\end{array}$ & Wistar rat & $\begin{array}{l}\text { VPA induced skeletal malformations } \\
\text { in skull, vertebrae and ribs were able } \\
\text { to prevent by Folate administration. }\end{array}$ & Ubeda et al..$^{58}$ \\
\hline Vitamin $\mathrm{E}$ & $\begin{array}{l}250 \text { and } 500 \\
\mathrm{mg} / \mathrm{kg} \\
\text { (oral) }\end{array}$ & Valproic acid (VPA) & $\begin{array}{l}700 \mathrm{mg} / \mathrm{kg} \\
(\mathrm{sc})\end{array}$ & Balb mice & $\begin{array}{l}\text { Concomitant administration of } \\
\text { vitamin E significantly attenuated } \\
\text { VPA induced decrease in the fetal } \\
\text { weight, crown rump length and } \\
\text { malformations. }\end{array}$ & Al Deeb et al. ${ }^{29}$ \\
\hline $\begin{array}{l}\text { S-adenosyl } \\
\text { methionine } \\
\text { (SAM) }\end{array}$ & $\begin{array}{l}10 \mathrm{mg} / \mathrm{kg} / \mathrm{d} \text { from } \\
\text { days } \mathrm{I}-10\end{array}$ & Valproate (VPA) & $\begin{array}{l}300 \mathrm{mg} / \mathrm{kg} / \mathrm{d} \\
\text { on days } 8,9 \\
10 \text { of } \mathrm{GD}\end{array}$ & Wistar rat & $\begin{array}{l}\text { VPA induced skeletal malformations } \\
\text { in skull, vertebrae and ribs whereas } \\
\text { SAM-co administration did not show } \\
\text { more protective action. }\end{array}$ & Ubeda et al..$^{58}$ \\
\hline $\begin{array}{l}\text { Folic acid } \\
\text { and } \\
\text { Pantothenic acid }\end{array}$ & $\begin{array}{l}3 \times 4 \mathrm{mg} \text { per } \mathrm{kg} \\
\text { ip GD } 5-10 \\
3 \times 200 \mathrm{mg} / \mathrm{kg} \text { ip } \\
\text { GD } 9\end{array}$ & Valproic acid & $\begin{array}{l}400 \mathrm{mg} / \mathrm{kg} \\
\mathrm{GD} 9 \\
\text { (s.c.) }\end{array}$ & CD-I mice & $\begin{array}{l}\text { Folic acid and } \\
\text { Pantothenic acid protect NTDs } \\
\text { by independent, but not mutually } \\
\text { exclusive mechanisms. }\end{array}$ & Dawson et al. ${ }^{17}$ \\
\hline Ascorbic Acid & $5 \mathrm{mM}$ & Valproic Acid & $\begin{array}{l}50,100,200 \\
400 \mu g / m l\end{array}$ & $\begin{array}{l}\text { CD-I } \\
\text { mouse }\end{array}$ & $\begin{array}{l}\text { The presence of ascorbic acid in } \\
\text { the culture media was effective in } \\
\text { protecting embryos against oxidative } \\
\text { stress induced by VPA and prevented } \\
\text { VPA-induced inhibition of Hoxa2 } \\
\text { gene expression. }\end{array}$ & Zhang et.al. ${ }^{36}$ \\
\hline
\end{tabular}

\section{Conclusion}

In light of all these observations and considering ongoing overview it appears that although the work on Antiteratogen is inadequate, scanty, and showing an initial and perfunctory interest in this field yet the data regarding the mechanisms of oxidative stress and oxidative damage was involve in VPA-induced teratogenesis are concluded the responsible for it, however more mechanistic studies are require for searching any others possibility for toxicity. So, more studies are also required to reveal the curtailing its oxidative damage and interactions in signaling pathways that inducing by VPA or its metabolites in the developing embryo causing teratogenicity or birth defects.

\section{Acknowledgements}

Mrs. Vimala Bind contributing in the preparation of manuscript.

\section{Conflict of interest}

The author declares that there is no conflict of interests regarding the publication of this paper.

\section{References}

1. Bourgeois B. Chronic management of seizures in the syndromes of idiopathic generalized epilepsy. Epilepsia. 2003;44(2):27-32. 
2. Bowden C. Valproate:Textbook of Psychopharmacology. Arlington: American Psychiatric Publishing Inc; 2009.

3. Burton BS. On the propyl derivatives and decomposition products of ethylacetoacetate. Am Chem J. 1982;3:385-395.

4. Chambers CD, Polifka JE, Friedman JM. Drug safety in pregnant women and their babies: ignorance not bliss. Clin Pharmacol Ther. 2008;83(1):181-183.

5. Dalens B, Raynaud EJ, Gaulme J. Teratogenicity of valproic acid. $J$ Pediatr. 1980;97:332-333.

6. Bjerkedal T, Czeizel A, Goujard J, et al. Valproic acid and spina bifida. Lancet. 1982;2(8307):1096.

7. Lammer EJ, Sever LE, Oakley GP. Teratogen update: valproic acid. Teratology. 1987;35(3):465-473.

8. Kao J, Brown NA, Schmid B, et al. Teratogenicity of valproic acid: In vivo and in vitro investigations. Teratog Carcinog Mutagen. 1981;1(4): 367-382.

9. Paulson RB, Sucheston ME, Hayes TG, et al. Teratogenic effects of valproate in the CD-1 mouse fetus. Arch Neurol. 1985;42(10):980-983.

10. Petrere JA, Anderson JA, Sakowski R, et al. Teratogenesis of calcium valproate in rats. Toxicol Sci. 1986;3(2):121-126.

11. Vorhees CV. Teratogenicity and developmental toxicity of valproic acid in rats. Teratology. 1987;35(2):195-202.

12. Petrere JA, Anderson JA, Sakowski R, et al. Teratogenesis of calcium valproate in rats. Toxicol Sci. 1986;3(2):121-126.

13. Esaki K, Tanioka Y, Ogata T, et al. Influence of sodium dipropylacetate (DPA) on the fetuses of the rhesus monkey. CIEA Preclin Rep. 1975;157164.

14. Ornoy A. Valproic acid in pregnancy: how much are we endangering the embryo and fetus?. Reprod Toxicol. 2009;28(1):1-10.

15. Clayton-Smith J, Donnai D. Fetal valproate syndrome. J Med Genet. 1995;32:724-727.

16. Yerby MS. Management issues for women with epilepsy: neural tube defects and folic acid supplementation. Neurology. 2003;61(6):S23-S26.

17. Dawson JE, Raymond AM, Winn LM. Folic acid and pantothenic acid protection against valproic acid-induced neural tube defects in CD-1 mice. Toxicol Appl Pharmacol. 2006;211(2):124-32.

18. Kouzarides T. Chromatin modifications and their function. Cell. 2007;128(4):693-705.

19. Eberharter A, Becker P. Histone acetylation: a switch between repressive and permissive chromatin. EMBO Rep. 2002;3(3):224-29.

20. Grant PA, Eberharter A, John S, et al. Expanded lysine acetylation specificity of Gen5 in native complexes. J Biol Chem. 1999;274(9):5895900 .

21. Van Lint C, Emiliani S, Verdin E. The expression of a small fraction of cellular genes is changed in response to histone hyperacetylation. Gene Expr. 1996;5(4):245-53.

22. Gurvich N, Tsygankova OM, Meinkoth JL, et al. Histone deacetylase is a target of valproic acid-mediated cellular differentiation. Cancer Res. 2004;64(3):1079-86.

23. Kramer OH, Zhu P, Ostendorff HP, et al. The histone deacetylase inhibitor valproic acid selectively induces proteasomal degradation of HDAC2. Eur Mol Biol Org J. 2003;22(13):3411-20.
24. Phiel CJ. Histone Deacetylase is a Direct Target of Valproic Acid, a Potent Anticonvulsant, Mood Stabilizer, and Teratogen. J Biol Chem. 2001;276(39):36734-36741.

25. Gurvich N, Berman MG, Wittner BS, et al. Association of valproateinduced teratogenesis with histone deacetylase inhibition in vivo. FASEB J. 2005;19(9):1166-1168.

26. Wells PG, McCallum GP, Chen C, et al. Oxidative stress in developmental origins of disease: teratogenesis, neurodevelopmental deficits, and cancer. Toxicol. Sci. 2009;108(1):4-18.

27. Sahambi SK, Hales B. Exposure to 5-bromo-2'-deoxyuridine induces oxidative stress and activator protein-1 DNA binding activity in the embryo. Birth Defects Res A Clin Mol Teratol. 2006;76(8):580-591.

28. Fantel AG. Reactive oxygen species in developmental toxicity: review and hypothesis. Teratology. 1996;53(3):196-217.

29. Al Deeb S, Al Moutaery K, Arshaduddin M, et al. Vitamin E decreases valproic acid induced neural tube defects in mice. Neurosci Lett. 2000;292(3):179-82.

30. Winn LM, Wells PG. Phenytoin-initiated DNA oxidation in murine embryo culture, and embryo protection by the antioxidative enzymes superoxide dismutase and catalase: evidence for reactive oxygen species-mediated DNA oxidation in the molecular mechanism of phenytoin teratogen. Mol Pharmacol. 1995;48(1):112-120.

31. Dennery P. Effects of oxidative stress on embryonic development. Birth Defects Res C Embryo Today. 2007;81(3):155-62.

32. Tong V, Teng XW, Chang TK, et al. Valproic acid I: time course of lipid peroxidation biomarkers, liver toxicity, and valproic acid metabolite levels in rats. Toxicol Sci. 2005;86(2):427-35.

33. Jurima-Romet M, Abbott FS, Tang W, et al. Cytotoxicity of unsaturated metabolites of valproic acid and protection by vitamins $\mathrm{C}$ and $\mathrm{E}$ in glutathione-depleted rat hepatocytes. Toxicology. 1996;112(1):69-85.

34. Defoort EN, Kim PM, Winn LM. Valproic acid increases conservative homologous recombination frequency and reactive oxygen species formation: a potential mechanism for valproic acid-induced neural tube defects. Mol Pharmacol. 2006;69(4):1304-1310.

35. Na L, Wartenberg M, Nau H, et al. Anticonvulsant valproic acid inhibits cardiomyocyte differentiation of embryonic stem cells by increasing intracellular levels of reactive oxygen species. Birth Defects Res Part A-Clin Mol Teratol. 2003;67(3):174-80.

36.Zhang B, Wang X, Nazarali AJ. Ascorbic acid reverses valproic acidinduced inhibition of hoxa2 and maintains glutathione homeostasis in mouse embryos in culture. Cell Mol Neurobiol. 2010;30(1):137-48.

37. Alsdorf R, Wyszynski DF. Teratogenicity of sodium valproate. Expert Opin Drug Saf. 2005;4(2):345-353.

38. Lindhout D. Valproate and spina bifida in the Netherlands. Absts Eur Teratol Soc. 1984; 60-61.

39. Lindhout D, Schmidt D. In-utero exposure to valproate and neural tube defects. Lancet. 1986;1(8494):1392-1393.

40. Elmazar MM, Thiel R, Nau H. Effect of supplementation with folinic acid, vitamin B6, and vitamin B12 on valproic acid-induced teratogenesis in mice. Fundam Appl Toxicol. 1992;18(3):389-94.

41. Ehlers K, Elmazar MM, Nau H. Methionine reduces the valproic acidinduced spina bifida rate in mice without altering valproic acid kinetics. $J$ Nutr. 1996;126(1):67-75.

42. Finkelstein JD. Methionine metabolism in mammals. J Nutr Biochem. 1990;1(5):228-37. 
43. Coelho, Klein. Methionine and neural tube closure in cultured rat embryos: morphological and biochemical analyses. Teratology. 1990;42(4):437451.

44. Padmanabhan R, Abdulrazzaq YM, Bastaki SMA, et al. Experimental Studies on Reproductive Toxicologic Effects of Lamotrigine in Mice. Birth Defects Res Part B-Dev Reprod Toxicol. 2003;68(5):428-438.

45. Copp AJ. Prevention of neural tube defects: vitamins, enzymes and genes. Curr Opin Neurol. 1998;11(2):97-102.

46. Lucock MD, Daskalakis I, Schorah CJ, et al. Folate-homocysteine interrelations: potential new markers of folate status. Mol Genet Metab. 199967(1):23-35

47. Kirke PN, Mills JL. Homocysteine metabolism in pregnancies complicated by neural tube defects. Nutrition 1997;13:994-5.

48. Rosenquist TH, Ratashak SA. Homocysteine induces congenital defects of the heart and neural tube: effect of folic acid. Proc Natl Acad Sci. 1996;93(26):15227-15232.

49. Kirke PN, Molloy AM, Daly LE, et al. Maternal plasma folate and vitamin B12 are independent risk factors for neural tube defects. QJ Med. 1993;86(11):703-8.

50. Roy M, Leclerc D, Wu Q, et al. Valproic acid increases expression of methylenetetrahydrofolate reductase (MTHFR) and induces lower teratogenicity in MTHFR deficiency. J Cell Biochem. 2008;105(2):467476.

51. Al-Gazali L. Abnormal folate metabolism and genetic polymorphism of the folate pathway in a child with down syndrome and neural tube defect. Am J Med Genet. 2001;103(2):128-132.
52. Ashfield Watt PA. Pullin L, Catherine H, et al. Methylenetetrahydrofolate reductase $677 \mathrm{C} \rightarrow \mathrm{T}$ genotype modulates homocysteine responses to a folate-rich diet or a low-dose folic acid supplement: A randomized controlled trial. Am J Clin Nutr. 2002;76(1):180-186.

53. Baran Ö, Nergiz Y, Tuncer MC. The effects of valporic acid, vitamin $\mathrm{E}$ and folic acid on ribs of rat fetuses in the prenatal period. Ann Anat. 2006;188(2):117-125.

54. Verrotti A, Scardapane A, Franzoni E, et al. Increased oxidative stress in epileptic children treated with valproic acid. Epilepsy Res. 2008;78(2):171-

55. Varoglu AO, Yildirim A, Aygul R, et al. Effects of valproate, carbamazepine, and levetiracetam on the antioxidant and oxidant systems in epileptic patients and their clinical importance. Clin Neuropharmacol. 2010;33(3):155-7.

56. Akhilesh Kumar, Hardik Chandasana, Rabi Sankar Bhatta, et al, Curcumin affords protection against valproic acid induced teratogenicity by curtailing oxidative stress and inhibiting CYP2C9 activity. RSC Adv. 2015;5:8275682764.

57. Bailey MM, Sawyer RD, Behling JE, et al. Prior exposure to indole-3carbinol decreases the incidence of specific cyclophosphamide-induced developmental defects in mice. Birth Defects Res B Dev Reprod Toxicol. 2005;74(3):261-267.

58. Ubeda N, Alonso Aperte E, Perez Miguelsanz J. Valproate induced effects on development in the rat are partially prevented by folinic acid and S-adenosylmethionine. Eur J Anat. 2000;4(1):23-33.

59. Winn LM, Wells PG. Maternal administration of superoxide dismutase and catalase in phenytoin teratogenicity. Free Radic Biol Med. 1999;26(34):266-274. 